\title{
Excessive Industrial Capacity Cutting and Steady Price: Dilemma of Supply-side Structural Reform
}

\author{
Xiaojie Fan \\ North china electricity power university, Beijing, China \\ Email237937795@qq.com
}

Keywords: Steel price; Overcapacity; Excessive industrial capacity cutting; The steel industry

\begin{abstract}
Since the beginning of 2016, under the overcapacity background of the iron and steel industry, the steel prices has increased sharply in the domestic and risen more than 50\% in less than half a year. This article first discusses the phenomenon and the reasons for rising in prices and analyzes the adverse impact of the production capacity of this round of steel price increasing and puts forward relevant policy suggestions.
\end{abstract}

\section{The Rising Steel Price Stimulates the Recovery Production and Increase Production of Steel Enterprises}

Now, much attention has been paid to the steel industry. One of the two industries of excessive industrial capacity cutting is steel. According to the Comment on resolving the over capacity of iron and steel industry to achieve the development by getting rid of poverty published by the state council, 45 million tons of excess capacity will be reduced this year in order to make steel product prices return to normal without low level competition and make the whole industry tend to be more healthy. From March 2016, Chinese steel prices began to rise and the amount of increase was about 1000 yuan. There is some fall but by the rebound in prices started in September 2016. According to data statistics of Sinosteel Corporation, the amount of increase of deformed steel bar used by the construction is $36 \%$ from the beginning of this year to the end of October while the cut deal used in ship is $42 \%$ and $36 \%$ in cold rolled coil plate used in car.

The main reason for this round of steel price increasing can be summarized into two aspects: first, on the demand side, one is the rise in steel demand expected due to the sales volume of large and medium-sized city commercial housing; Second, a lot of construction project is return to work after the break in winter which brings the demand growth of steel; Third, inventory supplement of the trader, which expanded the steel demand in the short term; Fourth, some policies such as the "supply the short board" and "steady growth" of market expectations will drive the steel demand; In the next place, on the supply side, one is the halt production of part steel mills last year that cause the steel production decline and reduce the market supply; Second, the market expectation of excessive industrial capacity cutting work will reduce steel production; third, part steel-producing region will take measures because of the major activities, which reduce the expected steel supply in short-term. In addition, the artificial speculation of spot and futures markets is also one of the important reasons of rapidly steel prices rising.

\section{The Challenges Bring by the Recovery Production of Steel Enterprises and the Health Industrial Development.}

Although recent steel rebounding is easing the predicament of iron and steel industry in a certain extent, a large number of inefficient capacity and production brings the challenges to "excessive industrial capacity cutting ".

Steel market recovery has weakened the excessive industrial capacity cutting of enterprise. After a quite long period of the steel market downturn, the reversed transmission effect of market mechanism is emerging, and some enterprises have shut down or take the initiative to cut capacity due to operating difficulties. Under the unified national deployment, excessive industrial capacity cutting works have been developed. The government took a total decomposition, standard reversed transmission, financial support and a series of measures to strive to cut steel production capacity 
and achieve good progress step by step. Recently, the steel market warming is burning the hope of the industries which have stopped production or about to. It not only weakened the will of excessive industrial capacity cutting but also more and more enterprises begin to join in recovery production and increase production. If the trend continues on, it may be great offset for excessive industrial capacity cutting measures. If the pace of recovery production and increase production is speed up, the marginal effect will be weakened and the contradiction between supply and demand of the market may intensify again, which will led the industry into a mire of low efficiency once again.

Improper administrative intervention may restrict industry transformation and upgrading. In production process, in order to complete the control target of total amount, some local governments have to take the task with administrative color means such as apportionment. Under the background of increasing recovery production impulse, the enterprise produces a greater resistance to excessive industrial capacity cutting and the market may be converted into social contradictions. Moreover, due to some differences of excessive industrial capacity cutting standards and enforcement policies between regions and enterprises, some enterprises which dare to break through the policy control may achieve the expansion of enterprise and some enterprises which strictly abide by the policy may be constrained miss the market opportunities. This will not only discourage the "law-abiding" positivity of enterprise but also can produce the adverse selection effect of "survival of the fittest ".

Sustainability of the domestic steel market recovery is still remained. Real estate and infrastructure investment recovery do not have long persistent. The real estate investment in three or four level cities accounted for about $70 \%$ but still on destocking. The recent amount of increase of steel price is rapid and great in short-term. Due to the real estate market regulation and monetary policy changes in the future, economic growth is still facing the risks and the steel price fluctuations may fluctuate sharply. Seen from the international market, the increasing steel exports in this year is suffered strong international trade friction than normal. From January to April this year, 15 trade remedy investigations have been launched by other countries and regions towards the steel productions in our country compared with 8 at the same period last year. It is close to double growth. Trade friction will form intensified suppression on steel export and the overcapacity contradictions in domestic steel industry will be further intensified.

\section{Policy Suggestion}

Iron and steel industry is a high degree of marketization of industry. The price rise and fall and the resulting increasing production should belong to normal phenomenon. Due to institutional constraints and policy restriction, the market does not automatically clearing and it is objective that the situation that the externalities of the industry cannot make internalization. Therefore, there are the suggestions to maintain the effective market mechanism and eliminate externalities and further clarify the capacity:

Firstly, weakening economic aggregates control means and strengthening environmental protection, safety standard and other reversed transmission mechanisms. Excessive industrial capacity cutting needs to try to circumvent the plans and administrative tasks apportionment method especially the forced demolition equipment by equipment size standards. At the same time, strengthen the use of social externalities such as environmental protection, energy consumption and security for reversed transmission excess capacity. From saving energy resources, strengthen environmental protection, social security, it should set energy-saving, environmental protection, quality and other functional regulatory standards such as collecting fees for discharging pollutants on the way to the internalization of external effects to make enterprises determine the capacity according to their own costs earnings.

Secondly, properly handle the employee allocation and debt disposal problems to keep the bottom line. Measured the capital requirements scientifically and raise funds to support enterprises in many cleaning which are unable to pay the worker wage arrears, resettlement of laid-off staff, reward or early exit enterprises, subsidies on schedule due to production capacity out of the local government financial difficulties and have a gap of social security; Accelerate the construction of social security system and make sure the insurance relations and transfer of personnel of 
unemployment of come off sentry duty; Improve the system of the laid-off workers reemployment; Construct the financial support system and establish the enterprise bad loans exit channel to reduce exit business debt risk of excessive debt; Improved the enterprise retreatment of capital market system to establish a smooth mechanism of transformation and liquidity assets form.

Thirdly, improve the relevant laws and regulations of bankruptcy system to speed up the bankruptcy disposal procedures; Gradually clear the jurisdiction power and administrative power of boundaries in the enterprise bankruptcy to strengthen the leading role of the enterprise bankruptcy court and make the enterprise bankruptcy system return to the judicial nature; Strengthen bankruptcy reorganization of judicial review to determine the associated enterprises merge bankruptcy rules and safeguard substantive justice; Protect the judicial power of bankruptcy cases to establish and improve the disciplinary mechanism.

Four is to improve the capacity of information statistical work to strengthen the industry monitoring and information disclosure of key industry; Strengthen the construction of key industries project information and services make related information system connectivity with environmental protection, finance, land to form coordinated supervision mechanism. At the same time, establish and improve the system of reporting and encourage and guide the social participation to strengthen the warning and guidance of market information.

\section{References}

[1] Lihua, Wang Xin.:Price theory and practice (2014)

[2] X.Y, L Dan: Metallurgical economics and management (2016)

[3] F.T.Jiang. Changsha: Central South University (2008)

[4] Information on http://www.yinhang123.net/zixun/ssxw/2016/1116/416093.html

[5] Information on http://news.orangeelectric.cn/index/item/id/103232.html

[6] Information on http://www.dzwww.com/shandong/sdnews/201609/

[7] Waters L.: Journal of Occupational and Organizational Psychology(2007)

[8] Information on http://mt.sohu.com/20150911/n420882681.shtml

[9] Information on http://www.qlwb.com.cn/2016/0119/536729.shtml

[10]Wanberg C R, Zhu J, Kanfer R,et al. After the pink slip: Academy of Management Journal(2012) 